\section{Photoelectric Cells.}

Photocells and their Application. By Dr. V. K. Zworykin and Dr. E. D. Wilson. Pp. xi +209. (New York: John Wiley and Sons, Inc.; London: Chapman and Hall, Ltd., 1930.) $12 s .6 d$. net.

【 NTIL recently, there was a serious lack of really representative books dealing with the theory and practice of the photoelectric and selenium cells. Happily, this no longer exists, thanks to Dr. Campbell and Miss Ritchie-whose exhaustive book is already in its second edition-and to Mr. G. P. Barnard, whose recent treatise on the selenium cell, though perhaps not so critical a survey of the subject as it might have been, will certainly be regarded as a standard reference work.

It may be said at once that the book under review cannot be classed with these. Probably the authors did not intend that it should be, their claim being that the aim of the book is to introduce the general public to the modern 'electric eye', and to teach the layman its normal characteristics and its special idiosyncrasies.

In spite of the authors' belief that the book presents an understandable account " not too technical for the untrained man and not too shallow for the specialist", we would hesitate to say that it has achieved its object. There are, however, certain classes of workers to whom the book will prove of use : those interested in the construction of photoelectric cells, and more especially sound-film engineers and others concerned with the general problem of amplification of photoelectric currents and with any of the almost endless applications.

The first six chapters are devoted chiefly to the theory and construction of the gas-filled and vacuum cells, though the treatment is not so exhaustive as in Dr. Campbell and Miss Ritchie's book. A good deal of Chapter ii., on general theory, seems rather unnecessary. Does the reader really expect, or want, a chart of the entire spectrum of radiant energy, or a description of black body radiation extending over several pages, in a book of this kind?

Chapter vii. is an isolated one entitled "Photoconductive and Photovoltaic cells", and serves to illustrate the main criticism of the book, that in some chapters the treatment is not sufficiently thorough for the specialist. This chapter, for example, introduces us to the selenium cell (to which Mr. Barnard devoted 331 pages), the thalofide cell, and one or two photovoltaic cells, all in nine pages. There is scarcely any further reference to them throughout the book.

Two chapters (viii. and ix.) discuss various photocell circuits and the problem of amplification. There are short chapters on the use of cells in soundfilm work, the electrical transmission of pictures, and in television. In a chapter on miscellaneous applications, some fifteen illustrations (again very condensed) are given of operations which the cell can perform. The last chapter discusses directions in which progress may be expected towards the discovery of the ideal cell. Several appendices are given at the end of the book. $\quad$ F. C. T.

\section{Our Bookshelf.}

A Manual of Practical Vertebrate Morphology. By J. T. Saunders and S. M. Manton. Pp. viii + 220. (Oxford: Clarendon Press; London: Oxford University Press, 1931.) 15s. net.

THIS text-book of practical work in vertebrate morphology covers the course for the first part of the Natural Sciences Tripos at Cambridge. Its contents are as follows. First, directions are given for the examination and dissection of the following types: The lamprey, the skate, the whiting, the auditory ossicles and swim-bladder of the roach, the salamander, the central and sympathetic nervous system of the frog, the lizard, the grass snake, the pigeon, and the brain of the sheep. The authors have not included an account of a general dissection of a mammal, "as many excellent accounts of the dissection of the rabbit are easily available".

The descriptions are good and the dissections are well planned. The authors have wisely refrained from inserting into these chapters discussions of the functions or evolutionary significance of the parts displayed, leaving such matters to the theoretical text-books that must be read in parallel with a practical course of this nature. But they append, after the chapters dealing with the dissections, a brief and highly compressed theoretical account of the vertebrate nervous system. In the reviewer's opinion, it would have been wiser to leave this also to the theoretical books, where it can be given more spacious treatment. Finally, there are four chapters dealing with the skeleton, in which the type system is abandoned and the different regions are taken one by one and examined in a great variety of animals.

The book is attractively illustrated and contains a number of useful and original features.

$$
\text { G. P. W. }
$$

Science and Religion : a Symposium. Pp. vii $+\mathbf{1 7 5}$. (London: Gerald Howe, Ltd., 1931.) 4s. 6d. net. IF a series of popular broadcast talks on science and religion is to be commended at all, the publication of the talks in print is certainly to be com. mended, because the peculiar danger of this form of instruction is that there should be left upon the

No. 3212, VoL. 127] 